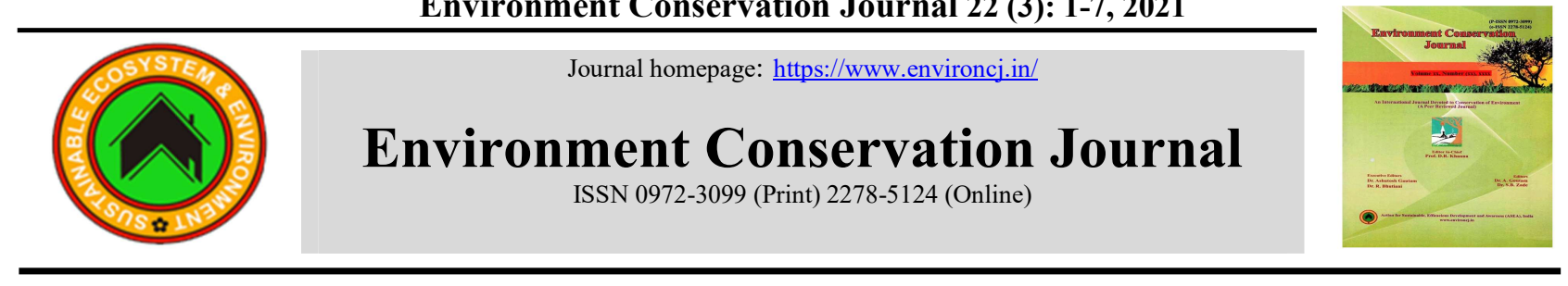

\title{
Efficacy of chitosan on growth and yield traits of mulberry, Morus
}

sp.

K. Thanga roja 政

Department of Sericulture, Forest College \& Research Institute Tamil Nadu Agricultural University Mettupalayam

K.A. Murugesh

Department of Sericulture, Forest College \& Research Institute Tamil Nadu Agricultural University Mettupalayam

P. Mangammal

Department of Sericulture, Forest College \& Research Institute Tamil Nadu Agricultural University Mettupalayam.

R. Shanmugam

Department of Sericulture, Forest College \& Research Institute Tamil Nadu Agricultural University Mettupalayam

\begin{tabular}{|c|c|}
\hline ARTICLE INFO & ABSTRACT \\
\hline $\begin{array}{l}\text { Received : } 19 \text { May } 2021 \\
\text { Revised : 05 July } 2021 \\
\text { Accepted : } 10 \text { July } 2021 \\
\text { Available online: } 19 \text { November } 2021 \\
\text { Key Words: } \\
\text { Chitosan } \\
\text { Foliar application } \\
\text { Morus sp., } \\
\text { Mulberry varieties } \\
\text { Productivity }\end{array}$ & $\begin{array}{l}\text { Chitosan is biopolymer of glucosamine residues, nontoxic, biodegradable and } \\
\text { friendly to environment and it also helps to enhance crop production due to } \\
\text { their bioactivities. The present experiment was conducted to assess the efficacy } \\
\text { of chitosan on the growth and yield related attributes of mulberry, Morus sp. } \\
\text { with various concentrations such as } 25,50,75,100 \text { and } 125 \text { ppm. The chitosan } \\
\text { was sprayed thrice on } 15,30 \text { and } 45 \text { days after pruning (DAP) on the foliage of } \\
\text { three different mulberry varieties namely V1, MR2 and G4. The result } \\
\text { revealed that, irrespective of varieties, the foliar application of chitosan at } 75 \\
\text { ppm significantly increased the biometric as well as yield related attributes of } \\
\text { mulberry over other concentrations. Among the three varieties, V1 showed } \\
\text { more response to chitosan application than G4 and MR2. At } 75 \text { ppm, chitosan } \\
\text { showed marked effect on VI variety of mulberry and significantly increased } \\
\text { shoot length }(170.67 \text { cm), number of shoots per plant }(9.03) \text {, number of leaves } \\
\text { per shoot (29.48), leaf area }\left(220.26 \mathrm{~cm}^{2}\right) \text { and leaf area index }(2.72) \text { were } \\
\text { observed when compared with control. The application of chitosan at } 75 \text { ppm } \\
\text { significantly enhanced the yield traits namely weight of } 100 \text { leaves }(448.10 \mathrm{~g}) \text {, } \\
\text { leaf shoot ratio (1.45) and leaf yield }(14.01 \mathrm{MT} / \mathrm{ha} / \mathrm{harvest}) \text { in V1. }\end{array}$ \\
\hline
\end{tabular}

\section{Introduction}

Mulberry is one of the most important economic crops cultivated exclusive for silkworm rearing and it is the only host plant for Bombyx mori L. The mulberry contributes by 38.20 per cent in successful production of cocoon (Miyashita, 1986). Mulberry being a perennial crop and pruned frequently needs to be maintained properly with the application of recommended quantity of organic and inorganic fertilizers. Many-a-times, the poor soil health status of mulberry garden and improper management practices, lead to significant reduction in the quality of leaf. Under such circumstances, the leaf quality and biomass production can be improved by the application of soluble nutrients or elicitors on the leaves. In the last decade, there was global realization on the important role of chitosan as plant growth promoter due to its non-toxicity, biodegradability and biocompatibility for better growth and yield of crops (Elieh-Ali-Komi and Hamblin, 2016). Chitosan is a natural, co-polymer of glucosamine and $\mathrm{N}$-acetyl -D-glucosamine obtained from the shells of marine organisms as shrimp, crab and prawn; insects, mushrooms and cell wall of microorganisms. The chitosan has been used as a fertilizer to increase the plant productivity (Nitar et al., 2004), to protect plants against microorganisms (Faruok et al., 2000), against oxidative stress (Guan et al., 2004) and to stimulate plant growth (Farouk et al., 2008 and 2011). Recently, few researchers have reported that

Corresponding author E-mail: rojathanga@gmail.com

Doi: https://doi.org/10.36953/ECJ.2021.22301

This work is licensed under Attribution-Non Commercial 4.0 International (CC BY-NC 4.0)

(C) ASEA 
chitosan enhanced plant growth of cucumber (Farouk et al., 2008), sweet pepper (Farouk et al., 2011), raddish (Ghoname et al., 2010), strawberry (Abdal-Mawgoud et al., 2010), bean (Sheikha and Al-Malki, 2011), tomato and egg plant (Sultana et al., 2017) by increasing the activity of enzymes involved in nitrogen metabolism. To the best of our knowledge, there is no previous report regarding the effect of foliar application of chitosan as an elicitor on growth of mulberry. Considering the above facts, the present work was undertaken to study the effect of chitosan on growth and yield attributes of different mulberry varieties.

\section{Material and Methods \\ i) Mulberry garden}

Field experiments were conducted at Department of Sericulture, Forest College and Research Institute, Mettupalayam (Latitude $11.20^{\circ} \mathrm{N}$; Longitude $76.56^{\circ} \mathrm{N}$ ) with foliar application of various concentrations of chitosan on three different mulberry varieties. The well-established three years old mulberry garden having varieties viz., V1, MR2 and G4, planted with the spacing of $90 \times 90 \mathrm{~cm}$ was used for the study. Package of practices recommended for irrigated condition of mulberry garden were followed throughout the study period (Dandin and Giridhar, 2014).

\section{ii) Preparation of chitosan solution}

The chitosan was extracted from mulberry silkworm pupae with chemical method (Battampara et al., 2020) and diluted in 2 per cent lactic acid. Then, it was dissolved in required quantity of distilled water to arrive at different concentrations viz., $25 \mathrm{ppm}(25 \mathrm{mg} / \mathrm{l}), 50 \mathrm{ppm}(50 \mathrm{mg} / \mathrm{l}), 75 \mathrm{ppm}$ $(75 \mathrm{mg} / \mathrm{l}), 100 \mathrm{ppm}(100 \mathrm{mg} / \mathrm{l})$ and $125 \mathrm{ppm}(125$ $\mathrm{mg} / \mathrm{l})$. The plots sprayed with distilled water and untreated control was maintained for comparison. The chitosan was uniformly applied on the mulberry foliage with knapsack sprayer on 15, 30 and 45 days after pruning (DAP).

\section{iii) Observations and statistical analysis}

The observations on growth traits viz., shoot length, number of shoots per plant, internodal length, number of leaves per shoot, leaf area, leaf area index, and yield traits viz., weight of 100 leaves, leaf shoot ratio and leaf yield were recorded on 70 DAP. The experiments were conducted in Randomized Block Design (RBD) with three replications. The collected data were analyzed statistically as described by Gomez and Gomez (1984). Treatment means and interaction effects were compared using critical difference at 5\% level of significance.

\section{Results and Discussion}

The application of chitosan on mulberry foliage had greater beneficial influence on growth of mulberry. The result on growth and yield attributes of mulberry have been analysed statistically that are presented in detail hereunder.

\section{A. Shoot attributes of mulberry}

The foliar application of chitosan elucidated positive significant effect on shoot attributes of mulberry (Table 1). Among the various concentrations, significantly higher shoot length $(154.37 \mathrm{~cm})$ and number of shoots per plant $(8.35)$ was recorded in chitosan $75 \mathrm{ppm}$ over the control, which was followed by $100 \mathrm{ppm}$. Here, the concentrations namely 125 and $50 \mathrm{ppm}$ did not differ statistically. This is due to optimum level chitosan concentration leads to enhance the stomatal mechanism at a right time and increases the leaf metabolism in plants (Hidangmayum et al., 2019).

Regarding different mulberry varieties, V1 recorded longest shoot length $(154.37 \mathrm{~cm})$ and more number of leaves per shoot (8.39) followed by G4 (148.90 cm and 7.51, respectively) and MR2 (119.16 $\mathrm{cm}$ and 7.20 , respectively), which were found to differ significantly from each other.

In interaction between different concentrations and varieties, significantly maximum shoot length $(170.67 \mathrm{~cm})$ and high number of leaves per shoot (9.03) was recorded in the V1 variety at chitosan 75 ppm, which was statistically superior to all other treatments. At the same time, minimum shoot length of $109.12 \mathrm{~cm}$ and less number of shoots per plant of 6.12 were observed in MR2 at control. The stimulating effect of chitosan on plant growth in the present study might be attributed to an increase in the availability and uptake of water and essential nutrients through adjusting cell osmotic pressure, and reducing the accumulation of harmful free radicals by increasing antioxidants and enzyme activities as reported by Guan et al., (2009). The present observation is supported by the results AbuMuriefah (2013), who found that the application of chitosan at $200 \mathrm{mgL}^{-1}$ significantly increased the plant growth $(45.20 \mathrm{~cm})$ and number of branches 
Table 1: Impact of chitosan on shoot attributes of mulberry, Morus sp.

\begin{tabular}{|c|c|c|c|c|c|c|c|c|}
\hline \multirow{2}{*}{ Treatments } & \multicolumn{4}{|c|}{ Shoot length $(\mathrm{cm})$} & \multicolumn{4}{|c|}{ No. of shoots per plant } \\
\hline & V1 & MR2 & G4 & Mean & V1 & MR2 & G4 & Mean \\
\hline Chitosan 25 ppm & 154.44 & 118.67 & 145.56 & 139.56 & 8.37 & 7.35 & 7.51 & 7.74 \\
\hline Chitosan 50 ppm & 163.54 & 124.67 & 153.78 & 147.33 & 8.89 & 7.58 & 7.65 & 8.04 \\
\hline Chitosan 75 ppm & 170.67 & 128.78 & 163.67 & 154.37 & 9.03 & 7.81 & 8.20 & 8.35 \\
\hline Chitosan 100 ppm & 166.11 & 125.56 & 158.11 & 149.93 & 8.75 & 7.68 & 8.00 & 8.14 \\
\hline Chitosan 125 ppm & 159.42 & 115.54 & 148.67 & 141.21 & 8.62 & 7.72 & 7.56 & 7.97 \\
\hline Water spray & 146.56 & 111.78 & 138.76 & 132.37 & 7.56 & 6.16 & 6.86 & 6.86 \\
\hline Control & 146.32 & 109.12 & 136.76 & 130.73 & 7.52 & 6.12 & 6.82 & 6.82 \\
\hline Mean & 158.15 & 119.16 & 148.90 & 142.07 & 8.39 & 7.20 & 7.51 & 7.70 \\
\hline \multirow{3}{*}{$\mathrm{CD}(\mathrm{P}=0.05)$} & $T$ & \multicolumn{3}{|l|}{$4.39 * *$} & \multicolumn{4}{|c|}{$0.11 * *$} \\
\hline & $\mathbf{V}$ & \multicolumn{3}{|l|}{$2.53 * *$} & \multicolumn{4}{|c|}{$0.10 * *$} \\
\hline & $T \times V$ & \multicolumn{3}{|l|}{$7.33 *$} & \multicolumn{4}{|c|}{$0.13 *$} \\
\hline
\end{tabular}

*Significant, ** Highly Significant; Each value is mean of three replications and pooled mean of two crops

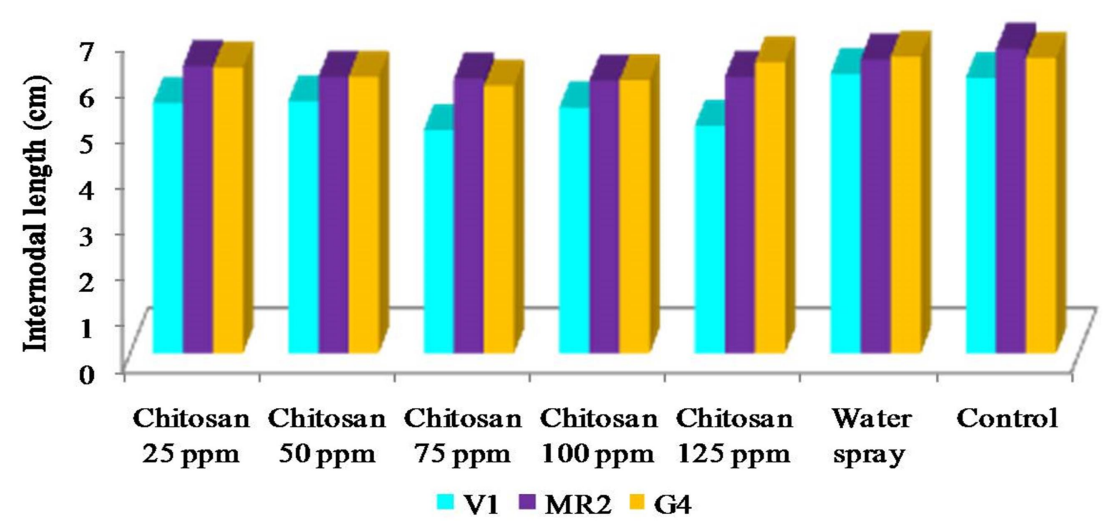

Figure 1: Impact of chitosan on internodal length of mulberry, Morus sp.

(9.50) on bean as compared to rest of the treatments. Our observations are in line with the findings of Lu et al., (2002), who observed that application of chitosan significantly increased the plant height and number of branches in rice. Further, the findings of Farouk et al. (2008) and Ghoname et al. (2010), who reported an increased vegetative growth and improvement in fruit quality due to the foliar application of chitosan in the crops like pepper, radish and cucumber were also strengthen the present observations.

As shown in Figure 1, the data indicated in different chitosan treatments and different mulberry varieties reduced the internodal length as compared with control. Among different concentrations evaluated, minimum internodal length of $5.56 \mathrm{~cm}$ was found in $75 \mathrm{ppm}$. This was followed by 100 ppm $(5.75 \mathrm{~cm})$, which was found to be statistically at par with $125 \mathrm{ppm}(5.79 \mathrm{~cm})$. Irrespective of the concentrations tested, lowest internodal length of $5.41 \mathrm{~cm}$ was observed in V1 variety. The next better variety was G4 $(6.15 \mathrm{~cm})$ which was found to be on par with MR2 $(6.17 \mathrm{~cm})$. In case of interaction, the reduced internodal length of 4.87 $\mathrm{cm}$ was registered in $\mathrm{V} 1$ variety at chitosan $75 \mathrm{ppm}$, whereas, MR2 showed higher internodal length of $6.64 \mathrm{~cm}$ in untreated plants. The findings of Chandrkrachang et al. (2003) and Boonlertnirun et al. (2005), who recorded reduced internodal length in the crops like chilli, celery and cucumber due to application of chitosan, support the present observations.

\section{B. Leaf attributes of mulberry}

The application of chitosan pronounced positive response in the leaf attributes of mulberry (Table 2 and Fig 2). The data in table 2 showed that leaf area increased by 51.29 per cent and number of leaves per shoot improved by 32.71 per cent over the 
Table 2: Impact of chitosan on leaf attributes of mulberry, Morus sp.

\begin{tabular}{|c|c|c|c|c|c|c|c|c|c|}
\hline \multirow{2}{*}{\multicolumn{2}{|c|}{ Treatments }} & \multicolumn{4}{|c|}{ No of leaves per shoot } & \multicolumn{4}{|c|}{ Leaf area $\left(\mathrm{cm}^{2}\right)$} \\
\hline & & V1 & MR2 & G4 & Mean & V1 & MR2 & G4 & Mean \\
\hline \multicolumn{2}{|c|}{ Chitosan 25 ppm } & 24.64 & 21.74 & 23.37 & 23.25 & 167.19 & 140.69 & 154.80 & 154.23 \\
\hline \multicolumn{2}{|c|}{ Chitosan 50 ppm } & 27.14 & 22.67 & 25.52 & 25.11 & 182.42 & 151.50 & 169.22 & 167.71 \\
\hline \multicolumn{2}{|c|}{ Chitosan 75 ppm } & 29.48 & 25.69 & 28.04 & 27.74 & 220.26 & 159.76 & 195.06 & 190.69 \\
\hline \multicolumn{2}{|c|}{ Chitosan 100 ppm } & 27.74 & 24.01 & 26.55 & 26.10 & 209.54 & 155.92 & 186.34 & 183.93 \\
\hline \multicolumn{2}{|c|}{ Chitosan 125 ppm } & 26.45 & 23.31 & 23.41 & 24.39 & 179.23 & 153.04 & 163.99 & 165.42 \\
\hline \multicolumn{2}{|c|}{ Water spray } & 22.85 & 18.36 & 21.45 & 20.89 & 135.51 & 117.01 & 133.31 & 128.61 \\
\hline \multicolumn{2}{|l|}{ Control } & 22.04 & 18.16 & 21.23 & 20.48 & 132.43 & 114.93 & 130.23 & 125.86 \\
\hline \multicolumn{2}{|l|}{ Mean } & 25.76 & 21.99 & 24.22 & 23.99 & 182.36 & 141.84 & 161.85 & 162.01 \\
\hline \multirow{3}{*}{$\mathrm{CD}(\mathrm{P}=0.05)$} & $\mathbf{T}$ & \multicolumn{4}{|l|}{$0.44 * *$} & \multicolumn{4}{|l|}{$4.32 * *$} \\
\hline & $\mathbf{V}$ & \multicolumn{4}{|l|}{$0.75 * *$} & \multicolumn{4}{|l|}{$2.44 * *$} \\
\hline & $\mathbf{T} \times \mathbf{V}$ & \multicolumn{4}{|l|}{$1.02 *$} & \multicolumn{4}{|l|}{$7.40 *$} \\
\hline
\end{tabular}

*Significant, ** Highly Significant; Each value is mean of three replications and pooled mean of two crops

Table 3. Impact of chitosan on yield attributes of mulberry, Morus sp.

\begin{tabular}{|c|c|c|c|c|c|c|c|c|c|}
\hline \multirow{2}{*}{\multicolumn{2}{|c|}{ Treatments }} & \multicolumn{4}{|c|}{ Weight of 100 leaves (g) } & \multicolumn{4}{|c|}{ Leaf shoot ratio } \\
\hline & & V1 & MR2 & G4 & Mean & V1 & MR2 & G4 & Mean \\
\hline \multicolumn{2}{|c|}{ Chitosan 25 ppm } & 400.60 & 353.60 & 377.10 & 377.10 & 1.23 & 1.09 & 1.17 & 1.16 \\
\hline \multicolumn{2}{|c|}{ Chitosan 50 ppm } & 423.30 & 360.30 & 412.90 & 398.83 & 1.32 & 1.17 & 1.20 & 1.23 \\
\hline \multicolumn{2}{|c|}{ Chitosan 75 ppm } & 448.10 & 370.50 & 435.80 & 418.13 & 1.45 & 1.29 & 1.35 & 1.36 \\
\hline \multicolumn{2}{|c|}{ Chitosan 100 ppm } & 433.90 & 366.30 & 422.30 & 407.50 & 1.34 & 1.20 & 1.26 & 1.29 \\
\hline \multicolumn{2}{|c|}{ Chitosan 125 ppm } & 411.30 & 370.90 & 393.30 & 391.83 & 1.26 & 1.19 & 1.21 & 1.22 \\
\hline \multicolumn{2}{|l|}{ Water spray } & 399.80 & 342.50 & 365.90 & 369.40 & 1.15 & 1.03 & 1.09 & 1.09 \\
\hline \multicolumn{2}{|l|}{ Control } & 398.84 & 339.10 & 362.70 & 366.88 & 1.12 & 1.02 & 1.07 & 1.07 \\
\hline \multicolumn{2}{|l|}{ Mean } & 416.55 & 358.46 & 395.71 & 391.10 & 1.27 & 1.14 & 1.19 & 1.20 \\
\hline \multirow{3}{*}{$\mathrm{CD}(\mathrm{P}=0.05)$} & $\mathbf{T}$ & \multicolumn{4}{|l|}{ 4.10* } & \multicolumn{4}{|l|}{ 0.04* } \\
\hline & $\mathbf{V}$ & \multicolumn{4}{|l|}{$5.40 *$} & \multicolumn{4}{|l|}{$0.04 *$} \\
\hline & $T \times V$ & \multicolumn{4}{|l|}{$11.53 \%$} & \multicolumn{4}{|c|}{$0.09 *$} \\
\hline
\end{tabular}

*Significant, ** Highly Significant; Each value is mean of three replications and pooled mean of two crops

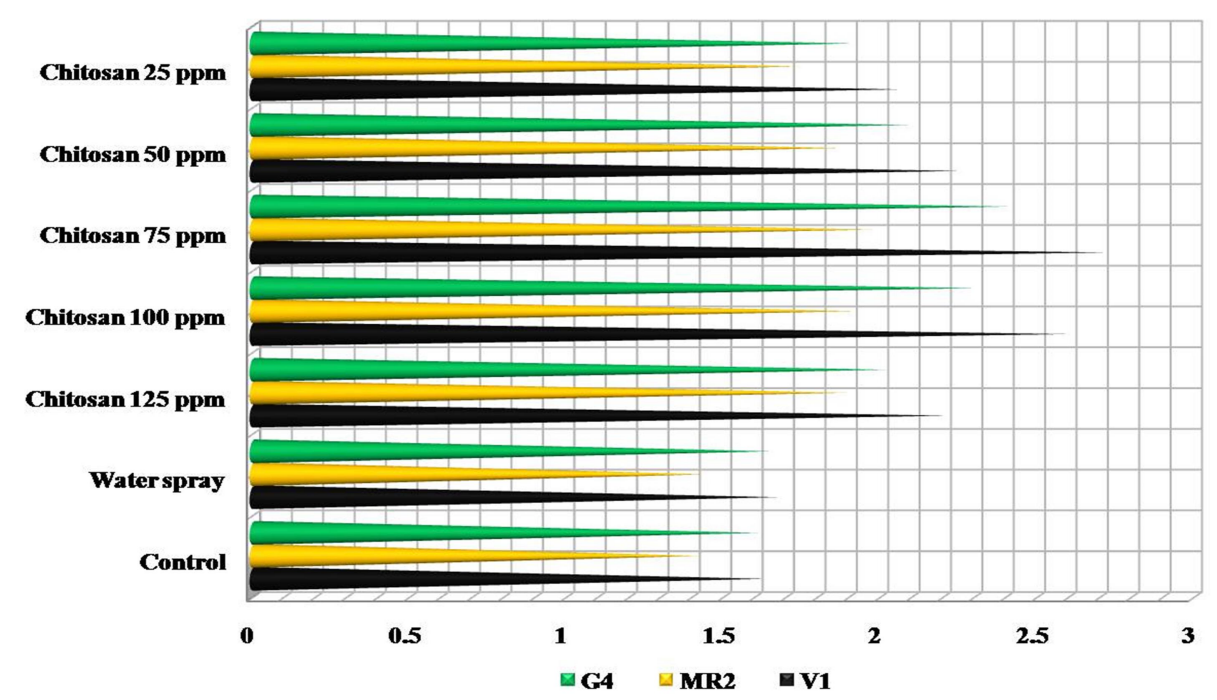

Figure 2: Impact of chitosan on leaf area index of mulberry, Morus sp. 
control. Among chitosan concentrations, significantly more number of leaves per shoot (27.74) and highest leaf area $\left(195.06 \mathrm{~cm}^{2}\right)$ was noticed in the plants sprayed with chitosan $75 \mathrm{ppm}$. The next better treatment was $100 \mathrm{ppm}$ which registered the value of 26.10 and $183.93 \mathrm{~cm}^{2}$ respectively. This might be due to increased photosynthetic activity in the functional leaves as reported by Gornik et al. (2008); Mondal et al. (2012) and, Ibraheim and Mohsen (2015). Mondal et al. (2012) found more number of leaves per plant (34.00) due to the chitosan application in okra, which supports the present observations. In respect of different mulberry varieties, significantly more number of leaves per shoot (25.76) and higher leaf area $\left(182.36 \mathrm{~cm}^{2}\right)$ was observed on V1 variety; whereas, less number of leaves per shoot (18.16) and lower leaf area $\left(114.93 \mathrm{~cm}^{2}\right)$ was noted on MR2 variety. In the interaction effect between different concentrations and varieties, number of leaves per shoot (29.48) and leaf area $\left(220.26 \mathrm{~cm}^{2}\right)$ was found to be significantly increased in V1 at chitosan $75 \mathrm{ppm}$, while, less number of leaves per shoot (18.16) and lowest leaf area $\left(114.93 \mathrm{~cm}^{2}\right)$ was observed in untreated plants of MR2. Our present study shown that chitosan treatments may be increases the leaf metabolism by stomatal mechanism which enhance the leaf area treated mulberry leaves. The results of our experiments are also in agreement with Hassnain et al., (2020), who recorded the higher number of leaves (104.19), leaf area $\left(81.05 \mathrm{~cm}^{2}\right)$ in tomato, and they attributed this to enhanced activities of enzymes involved in nitrogen metabolism namely glutamine synthetase, protease and nitrate reductase.

Leaf area index of different treatments and different varieties were presented in Figure 2. As found in above results, significantly higher leaf area index of 2.72 was observed on chitosan $75 \mathrm{ppm}$ of V1 compared to others. The present experimental results are also in conformity with Mondal et al. (2016), who reported increased number of leaves per plant (53.70) and leaf area plant ${ }^{-1}\left(2216 \mathrm{~cm}^{2}\right)$ due to the application of chitosan at $50 \mathrm{mg} \mathrm{L}^{-1}$ on tomato.

\section{Yield attributes of mulberry}

Application of chitosan at various concentrations has brought significant enhancement in different yield related attributes over the control (fig. 3). Among various concentrations, chitosan $75 \mathrm{ppm}$ recorded significantly higher weight of 100 leaves $(418.13 \mathrm{~g})$ and leaf shoot ratio (1.35) followed by chitosan $100 \mathrm{ppm}$ with the value of $407.50 \mathrm{~g}$, and $1.29 \mathrm{MT} / \mathrm{ha} /$ harvest, respectively. Among the different varieties, V1 registered maximum weight of 100 leaves $(416.55 \mathrm{~g})$ and leaf shoot ratio (1.27) as against minimum of $358.46 \mathrm{~g}$ and 1.14 , respectively in MR2.

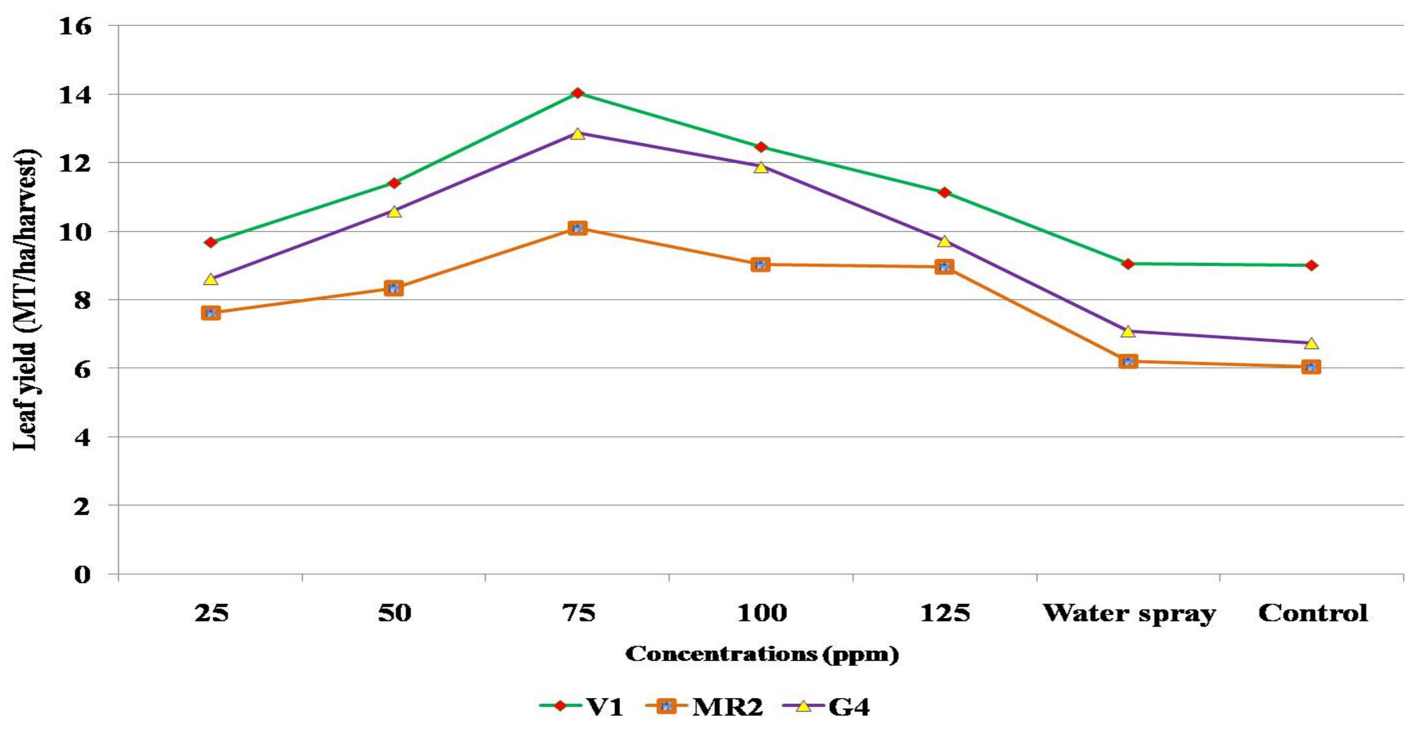

Figure 3: Impact of chitosan on leaf yield of mulberry, Morus sp. 
The interaction of chitosan concentrations and mulberry varieties showed that V1 at chitosan 75 ppm recorded significantly maximum weight of 100 leaves $(448.10 \mathrm{~g})$ and leaf shoot ratio (1.45). G4 variety at chitosan $75 \mathrm{ppm}$ was found to be next better treatment by recording significantly higher weight of 100 leaves $(437.80 \mathrm{~g})$ and leaf shoot ratio (1.38) over the control. The untreated plants in MR2 variety registered the lowest weight of 100 leaves $(339.10 \mathrm{~g})$ and leaf shoot ratio (1.02). The application of chitosan at $1 \mathrm{ml} \mathrm{L}^{-1}$ on cucumber recorded the highest yield of $4.86 \mathrm{~kg} \mathrm{plant}^{-1}$ as compared to control (Shehata et al., 2012).

Results in Figure 3 showed that improvement in leaf yield due to application of chitosan at $75 \mathrm{ppm}$ ranges from 2.48 to 64.74 per cent over the control. At the same as above results, chitosan $75 \mathrm{ppm}$ of V1 treated mulberry plants had highest leaf yield of $14.01 \mathrm{MT} / \mathrm{ha} /$ harvest and lowest was recorded in untreated plants in MR2 variety of 6.04 $\mathrm{MT} / \mathrm{ha} /$ harvest. Normally, MR2 has low yielding mulberry variety under moderate irrigate condition compared to $\mathrm{V} 1$ because $\mathrm{V} 1$ is high yielding ruling variety under normal irrigate condition. Here, V1 response to chitosan more effective compare to

\section{References}

Abdel-Mawgoud, A. M. R., Tantawy, A. S., El-Nemr, M. A., \& Sassine, Y. N. (2010). Growth and yield responses of strawberry plants to chitosan application. European Journal of Scientific Research, 39(1), 170-177.

Abu-Muriefah, S. S. (2013). Effect of chitosan on common bean (Phaseolus vulgaris L.) plants grown under water stress conditions. International Research Journal of Agricultural Science and Soil Science, 3(6), 192-199.

Battampara, P., Sathish, T. N., Reddy, R., Guna, V., Nagananda, G. S., Reddy, N., ... \& Radhakrishna, P. G. (2020). Properties of chitin and chitosan extracted from silkworm pupae and egg shells. International Journal of Biological Macromolecules, 161, 1296-1304.

Boonlertnirun, S., E. Sarobol and Sooksathan. 2005. Studies on chitosan concentration and frequency of foliar application on rice yield potential c.v Suphunburi $1.31^{\text {st }}$ Congress on Science and Technology of Thailand, October18-20, Suranaree University of Technology, Thailand, pp: 40-44.

Chandrkrachang, S., Sompongchaikul, P., \& Teuntai, S. (2003, July). Effect of chitosan applying in multicuture crop plantation. In National Chitin-Chitosan Conference July 17-18 (pp. 158-160). other mulberry varieties. Lee et al., (2005) found that chitosan treatment increased the yield and marketability of soybean sprouts. Trials conducted on tomatoes showed that foliar applications of chitosan increased the yield by 20 per cent (Walker et al., 2004). These findings fall more or less in line with the present observations.

\section{Conclusion}

It is concluded from the present study that foliar application of chitosan at $75 \mathrm{ppm}$ thrice on 15, 30 and 45 DAP on mulberry significantly enhanced the various growth and yield related attributes. However, chitosan 100 ppm and 125 ppm not much effective compare to optimum level due to increase the closure of stomata long time led to decreases the plant metabolism. From the present study revealed that all the mulberry varieties had good response to chitosan treatments compared to control under unstressed condition. Hence, it could be advocated for large scale field evaluation in order to successfully augmenting the foliage productivity without any damage to the ecosystem.

Dandin, S. B. \& Giridhar, K. (2014). Handbook of Sericulture Technologies. Central Silk Board, Bangalore, p. 389.

Elieh-Ali-Komi, D., \& Hamblin, M. R. (2016). Chitin and chitosan: production and application of versatile biomedical nanomaterials. International journal of advanced research, 4(3), 411.

Farouk, S., Ghoneem, K. M., \& Ali, A. A. (2008). Induction and expression of systemic resistance to downy mildew disease in cucumber by elicitors. Egypt. J. Phytopathol, 36(1-2), 95-111.

Farouk, S., Mosa, A. A., Taha, A. A., \& El-Gahmery, A. M. (2011). Protective effect of humic acid and chitosan on radish (Raphanus sativus, L. var. sativus) plants subjected to cadmium stress. Journal of Stress Physiology \& Biochemistry, 7(2).

Ghoname, A. A., El-Nemr, M. A., Abdel-Mawgoud, A. M. R., \& El-Tohamy, W. A. (2010). Enhancement of sweet pepper crop growth and production by application of biological, organic and nutritional solutions. Research Journal of Agriculture and Biological Sciences, 6(3), 349355.

Gomez, K. A., \& Gomez, A. A. (1984). Statistical procedures for agricultural research. John Wiley \& Sons. 
Górnik, K., Grzesik, M., \& Romanowska-Duda, B. (2008). The effect of chitosan on rooting of grapevine cuttings and on subsequent plant growth under drought and temperature stress. Journal of Fruit and Ornamental Plant Research, 16, 333-343.

Guan, Y. J., Hu, J., Wang, X. J., \& Shao, C. X. (2009). Seed priming with chitosan improves maize germination and seedling growth in relation to physiological changes under low temperature stress. Journal of Zhejiang University Science B, 10(6), 427-433.

Hassnain, M., Alam, I., Ahmad, A., Basit, I., Ullah, N., Alam, I., ... \& Shair, M. M. (2020). Efficacy of chitosan on performance of tomato (Lycopersicon esculentum L.) plant under water stress condition. Pak. J. Agric. Res, 33, 27-41.

Ibraheim, S. K. A., \& Mohsen, A. A. M. (2015). Effect of chitosan and nitrogen rates on growth and productivity of summer squash plants. Middle East J. Agric. Res, 4(4), 673-681.

Lu, J., Zhang, C., Hou, G., Zhang, J., Wan, C., Shen, G., \& Hou, T. (2002). The biological effects of chitosan on rice growth. Acta Agriculture Shanghai, 18(4), 31-4.

Lee, Y. S., Kim, Y. H., \& Kim, S. B. (2005). Changes in the respiration, growth, and vitamin $\mathrm{C}$ content of soybean sprouts in response to chitosan of different molecular weights. HortScience, 40(5), 1333-1335.

Miyashita, Y. (1986). A report on mulberry cultivation and training methods suitable to bivoltine rearing in Karnataka. Central Silk Board, Bangalore, India, 1-7.
Mondal, M., Puteh, A. B., \& Dafader, N. C. (2016). Foliar Application Of Chitosan Improved Morphophysiological Attributes And Yield In Summer Tomato (Solanum lycopersicum). Pakistan Journal of Agricultural Sciences, 53(2).

Mondal, M. M. A., Malek, M. A., Puteh, A. B., Ismail, M. R., Ashrafuzzaman, M., \& Naher, L. (2012). Effect of foliar application of chitosan on growth and yield in okra. Australian Journal of Crop Science, 6(5), 918-921.

Nitar, N., Chandrkrachang, S., \& Stevens, W. F. (2004). Application of chitosan in Myanmar's agricultural sector. In proceedings of sixth asia-pacific: chitin and chitosan symposium, E. Khor, D. Hutmacher, LL Yong (eds.), Singapore.

Shehata, S. A., Fawzy, Z. F., \& El-Ramady, H. R. (2012). Response of cucumber plants to foliar application of chitosan and yeast under greenhouse conditions. Australian Journal of Basic and Applied Sciences, 6(4), 63-71.

Sheikha, S. A., \& Al-Malki, F. M. (2011). Growth and chlorophyll responses of bean plants to the chitosan applications. European Journal of Scientific Research, 50(1), 124-134.

Walker, R., Morris, S., Brown, P., \& Gracie, A. (2004). Evaluation of potential for chitosan to enhance plant defense. A Report for the Rural Industries Research and Development Corporation, Australia. RIRDC Publication, (4). 
